\title{
THE CONCEPTS AND METHODS OF DZAWIL ARHAM HERITAGE CALCULATION: Analysis and Practice
}

\section{Raja Ritonga ${ }^{1}$}

\begin{abstract}
Dzawilarham is seen as a marginalized heir group. The position of the inheritance rights is a struggle between the pro and the contra among the ulama. The distribution of inheritance to the dzawilarham group by agreeing their inheritance rights opens the door of a goodness. Hifzu an-nasl (guarding descent) is one of the maqashid of Islamic law. The existence of dzawilarham as a family, relative or descendant deserves to be protected and embraced. This research is to describe the position of dzawilarham and to explain the concepts and practical methods in counting the parts of dzawilarham in Islamic inheritance. This research method uses literature study, namely conducting research on a number of references that are relevant to the discussion. The data were described and analyzed in a qualitative form. The result explain that the dzawilarham kinship pathway is bilateral, through the male route and the female route. The inheritance of dzawilarham is agreed by the majority of friends and ulamamazhab. The concept and determination of the inheritance of dzawilarham has three characteristics, mazhabahlu at-tanzil, mazhabahlu al-qorobah and mazhabahluar-rahmi. At the completion of the count of inheritance, the ahluar-rahmimazhab equalizes all the positions and the portion of the heirs. Meanwhile, the ahlu attanzilmazhab provides the portion of the dzawilarham according to the part of origin. While the ahlu al-qorobahmazhab completes the count of dzawilarham with the concept of inheritance of ashobah, close relatives block those who are far away.
\end{abstract}

Keywords: ahlu al-qorobah, ahlu at-tanzil, ahluar-rahmi, dzawilarham, heirs

\section{The Introduction}

The Alquran explains that the creation of humans was a process of a man and a woman(Indonesia, 2014). The foundation of the sakinah family is built with akad of mitsaqon gholizha between the men and women(Amri \& Tulab, 2018). Furthermore, human developed into tribes and nations so they can increase relations and relationships(Saadat, 2009). Because Islam is a religion that is very concerned with kinship ties(Haryanto, 2015).

Besides of establishing new family relationships(Fitriyati \& Zuhdi, 2020), marriage also aims to strengthen kinship. Because, family and relatives are the two things that concerned in a person's life(Darussalam, 2017). When a person dies, his family and relatives can fulfill the responsibility and part of his obligations(Nurhaliza, 2018). Then, his property and rights will also be transferred to his family and closest relatives. The process of transferring property and property rights is known as inheritance(Manangin et al., 2020).

Then, Islamic inheritance is regulated through kinship and marriage contracts. The closeness of kinship is a determining factor in obtaining inheritance(Wahyuni, 2018). Therefore kinship is an important part of the transfer of property and property rights of a person(Hasibuan, 2020). Kinship

1 Sekolah Tinggi Agama Islam Negeri Mandailing Natal, Email: rajaritonga@stainmadina.ac.id 
through male and female has its own characteristics. In general, male line relatives is dominatde and has an existence in a family. Meanwhile, women's pathways are only in a more limited scope(Kiswanto, 2019).

Islamic inheritance has a bilateral principle in the transfer of inheritance(Taqiyuddin, 2020). This means that someone can get the inheritance through the male route or the female route(Ritonga, 2020). A person can also give his property to the male line or the female line(Hadi, 2016). So that the determination of the share of the inheritance will involve the family and relatives of the male and female lines. This is in accordance with Q.S.4: 7 that men and women both have rights from both parents(Indonesia, 2014).

The inheritance group in Islam consists of three types, ashabul furudh, ashobah and dzawil arham(Washil, 1995:151-154). The position of dzawil arham is the third class in the Islamic inheritance system. They got heir when there were no ashabul furudh and ashobah groups(Qonun, 2010:274). The three types of inheritance groups have very contrasting differences. Ashabul furudh is a group of heirs that already have a certain portion(Qonun, 2010:76). While ashobah is a group of heirs whose parts are not determined, but have the remaining rights of ashabul furudh(Qonun, 2010:199). While dzawil arham is a heir group that has part portion with the ulama's ijtihad(Washil, 1995:202).

Furthermore, the Alquran reminds us to be careful not leave the weak descendants(Katsir, 1999, II:222). The ulama further interpreted that everyone does not leave behind weak physical, scientific, economic and position descendants(Qurtubi, n.d.V:51-53). The dzawil arham group is part of the relatives and descendants. Hifzu an-nasl (maintaining descent) is one of the goals of Islamic law(Achmad Beadie Busyroel Basyar, 2020). The distribution of assets by embracing all elements of the heir group is very likely to be done. Ashabul furudh gets inheritance through furudh almuqoddarah or certain parts. Ashobah received his portion with the concept of al-baqi. While dzawil arham can inherit through the will model of the heir(Ritonga, 2021a).

In general, dzawil arham heir groups are relatives of the deceased through the female line('Ajuz, 1986:221). However, a number of dzawil arham heirs also have male kinship to the deceased(Ritonga, 2021b). Dzawil arham heir groups are often understood as marginalized heirs. Because dzawil arham is only calculated after the heir groups of ashabul furudh and ashobah do not exist in a case. So that the opportunity for dzawil arham to get an inheritance is very limited and depends on the position of the other heirs(Aziz, 2006:54-56).

In the searches conducted, research related to dzawil arham has been carried out by several researchers. Among them is the research entitled "Dzaul Arham's Position Assurance in Islamic Inheritance through Wajiba's Will" the results of the study describe that to ensure the existence of dzawil arham, it is necessary to develop the concept of a mandatory will(Shesa, 2018). Then, the research "Inheritance Rights of Zawil Arham Persepectivemazhab Hanafiyah and Syafi'iyah" as a conclusion that the mazhab of Hanafiyah argues that dzawil arham get inheritance when there are no ashabul furudh and ashobah groups. Meanwhile, in the mazhabofsyafi'iyah, two models of thought emerge between prioritizing the 
right of dzawil arham or prioritizing the interests of the Islamic community, namely baitul mal(Sitti Suryani, 2018).

This research will describe in detail about the structure of the heirs of dzawil arham. Then, an analysis was carried out related to the position of dzawil arham and the process of determining the portion of each case. In addition, it will explain the concepts and methods of calculating practically the part of dzawil arham according to Islamic inheritance. So that the method offered can be a guide in the form of a practical or applicable.

\section{Research Methods}

This type of research is a research library and is qualitative in nature. In collecting research data, a number of reference books and research articles that are relevant to the object under study were carried out. In addition, the results of other scientific papers from theses, theses and dissertations are part of the data in this research.

Furthermore, all the data found were described and analyzed qualitatively. Then, the inheritance of the dzawil arham group is described in detail with a number of case examples. Then, themethod of calculating dzawil arham inheritance is used with practical and applicable methods. So that the description of the inheritance structure of dzawil arham, the parts and solutions of each case is easy to understand.

\section{Discussion and Results}

\section{Understanding Dzawil Arham}

The word ذاوي الأرحام (dzawil arham) comes from Arabic and consists of

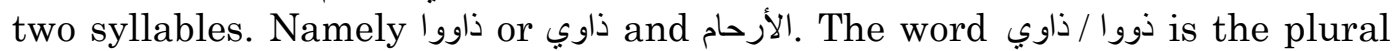
form of the word ذوا (dzu) which has the meaning of having(Ar-Rozi, 2003:131). Meanwhile, the word الرحم is also the plural form of the word الرحام (ar-rahim) which means womb or relative(Ar-Rozi, 2003:139). So that when the two words are combined, it will mean that dzawil arham is a person who has kinship through the uterine line.

While the meaning of dzawil arham in fiqh mawaris is a person who is not a group of ashabul furudh and not a group of ashobah(Washil, 1995:197). When ashabul furudh get inheritance with the furudh al muqoddaroh (certain parts) and ashobah with the jargon albaqi (residual), then the method of inheritance of the dzawil arham group is included in the ijtihad decisions of the sahabah and scholars of the mazhab of fiqh ('Ajuz, 1986:87).

\section{Heirs of Dzawil Arham}

In general, dzawil arham heirs are relatives or relatives of the deceased through the female route. They are more numerous than the ashabul furudh and ashobah groups('Ajuz, 1986:221). However, their groups can be classified based on their respective lineages. As outlined below:

\section{Dzawil arham of the bunuwah group}

Namely the dzawil arham group from the descendants of the deceased, they are the descendants of the biological daughter and the descendants of the granddaughter. 
Chart. 1

Dzawil arham of the bunuwah group

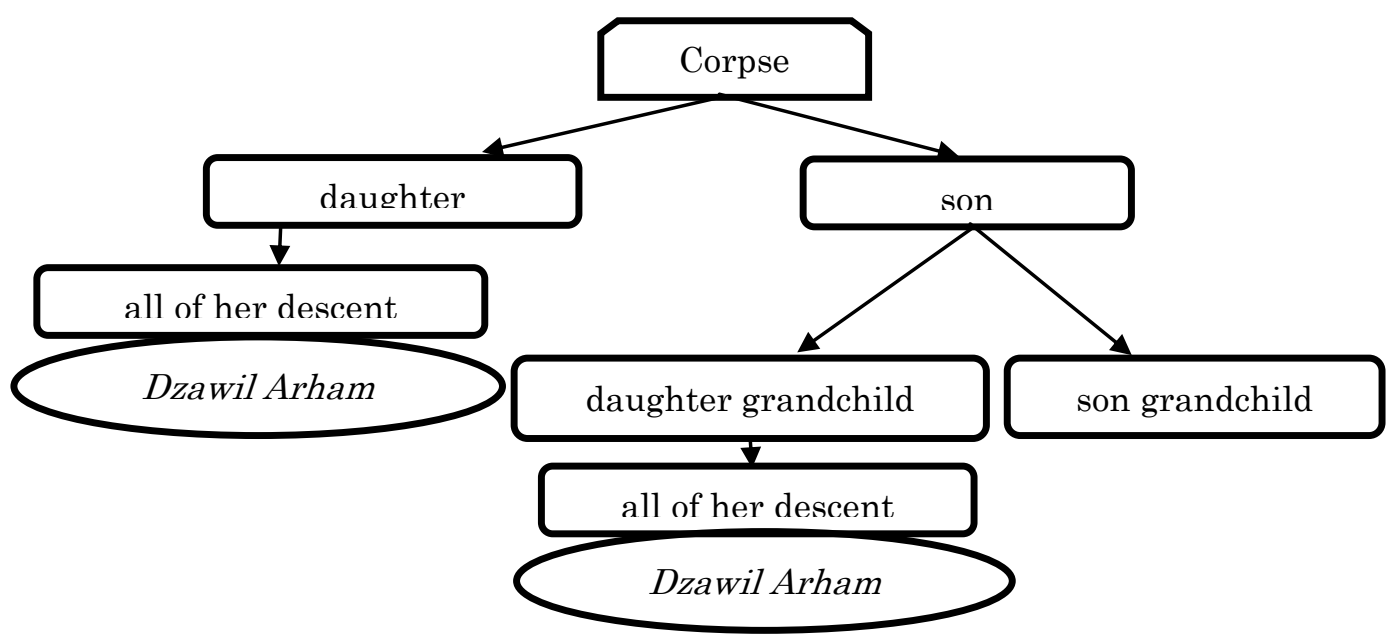

2. Dzawil arham of the ubuwah group

Namely the group of dzawil arham through the father and mother lines of the deceased. They are the father's sisters, maternal brothers and mother's sisters, fasid grandparents from the paternal line, fasid grandparents and fasidah grandmothers from the mother'sline.

Chart. 2

Dzawil arham of the ubuwah group

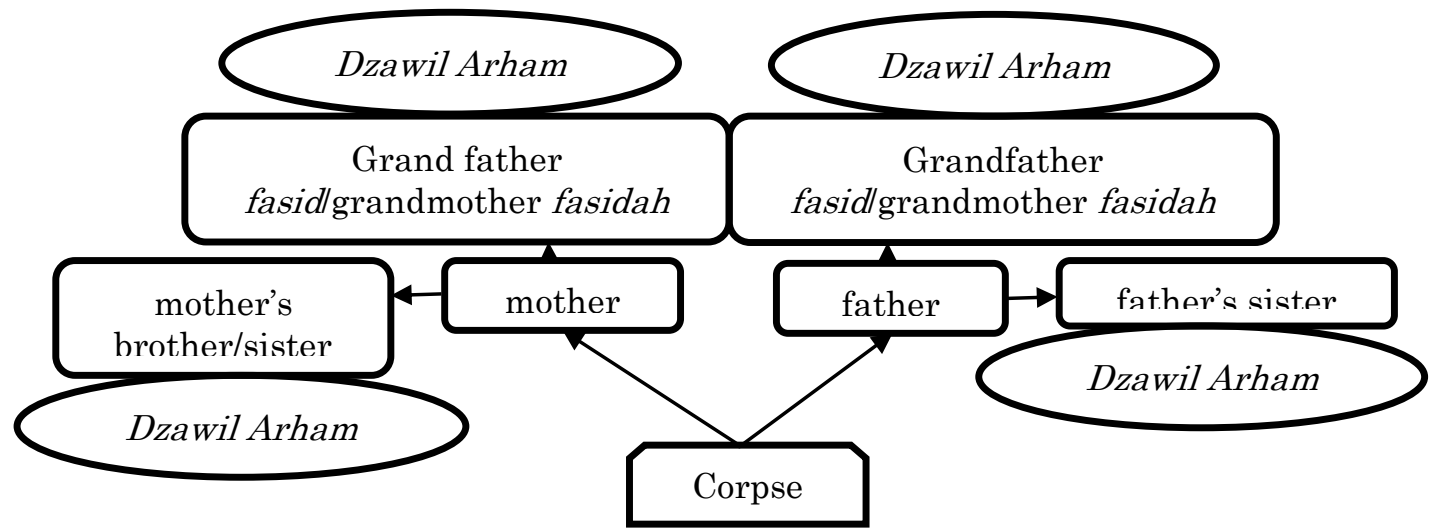

3. Dzawil arham of the ukhuwah group

Namely the group of dzawil arham from the line of brothers and sisters of the deceased. They are the daughters of siblings and descendants, sons and daughters of siblings and their descendants, daughters of step brothers of fatherand descendants, sons and daughters of step-sisters of father and their descendants, sons and daughters of step brothers of mother and their descendants, sons and daughters of step brothers of mother and brother sibling and his descendants, daughters of brother sibling and descendants and daughters of stepbrothers and descendants. 
Chart. 3

Dzawil arham of the ukhuwah group
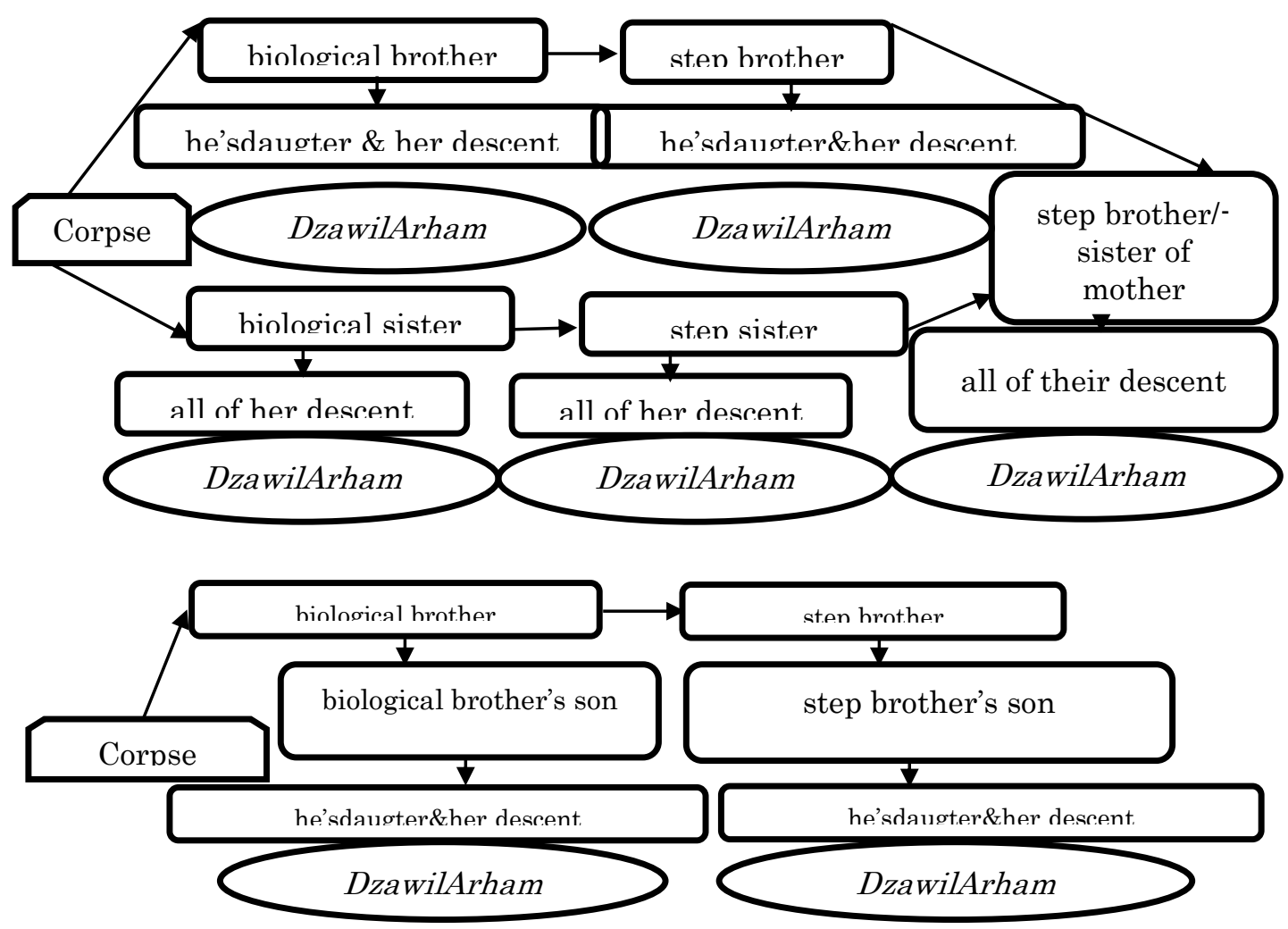

4. Dzawil arham of the 'umumah group

Namely the dzawil arham group from the line of the deceased uncle. They are the daughters of the biological uncles and their descendants, the daughters of the step-uncle's from father and their descendants, the daughters of the sons of the biological uncles and their descendants, the daughters of the sons of the step-uncle's from father and their descendants.

Chart. 4

Dzawil arham of the 'umumah group
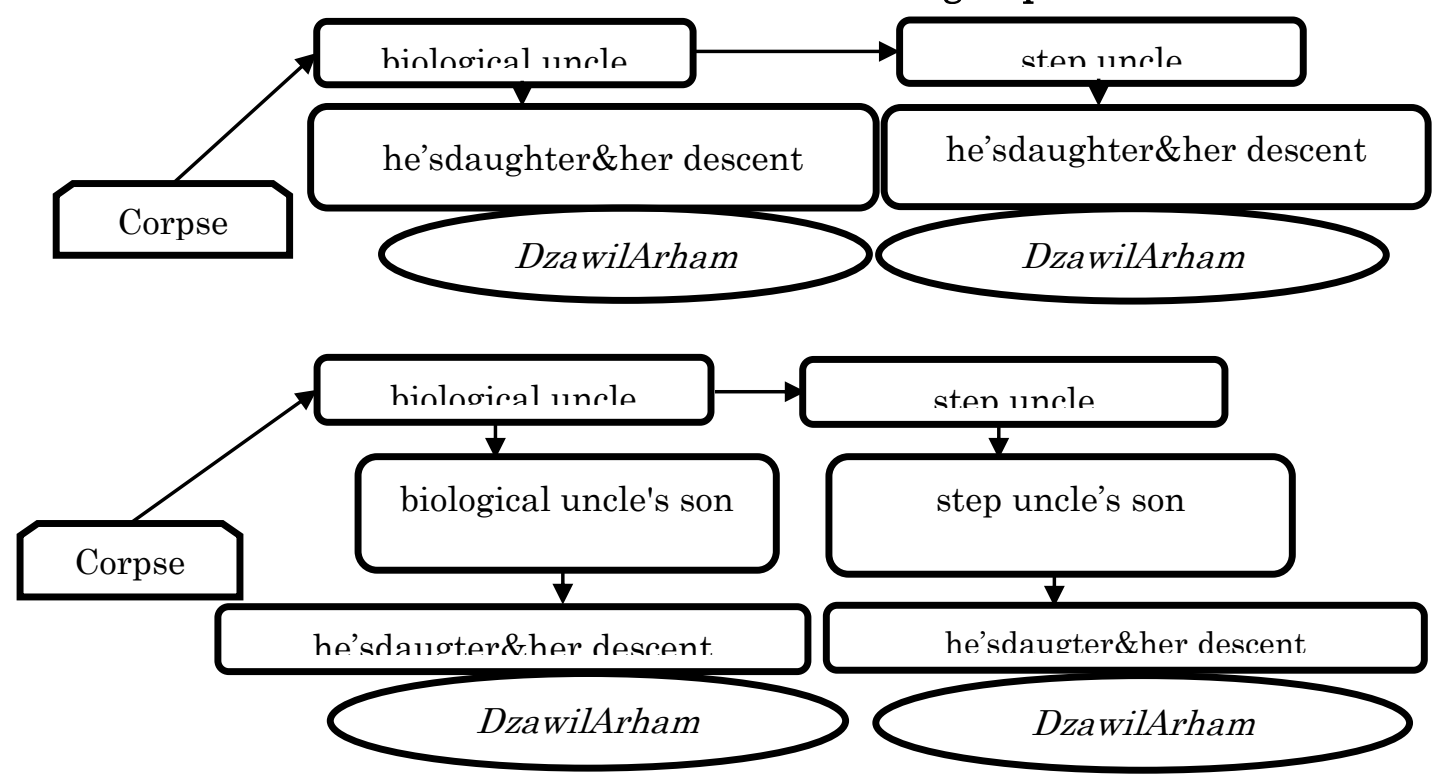


\section{Ulama's Opinion on Inheritance Rights of Dzawil Arham}

The Ulamahave different views regarding the inheritance rights of dzawil arham(Washil, 1995:199). This difference in perspective arises because there is no dalil by qot'i argument regarding to the inheritance rights of the dzawil arham group(Qonun, 2010:273). Besides of the issue of legality, the Ulama also see the principle of maslahat that results from the benefit of the inheritance to the recipient. So that the difference in legal decisions only focuses on prioritizing the rights of dzawil arham as part of the deceased's relatives or the inheritance is handed over to Baitul Mal as a representative of the Muslims who will receive benefits(Khalifah, 2005:485).

The first group has a view that dzawil arham has not a right to inheritance. This opinion comes from Zaid bin Thabit, Ibnu Abbas, Sa'id bin Musayyab, Sa'id bin Jubair, Imam Malik, Imam Syafi'i and the MazhabDzhohiri. They argue that there is no shorih argument that explains the inheritance of the dzawil arham group('Ajuz, 1986:221).

In addition, they also argued with a dalil that comes from 'Atha bin Yasar R.A., when Rasulullah Saw went to Quba, at that time he asked for instructions regarding the inheritance of' ammah (father's sister) and the kholah (mother's sister) section. At that time there was a wahyuexplaining that the two of them did not get inheritance(Khalifah, 2005:486).

The second group has a view that dzawil arham has the right to get inheritance. This opinion comes from a number of Sahabat, including Umar bin Khattab, Ali bin Abi Tholib, Abdullah bin Mas'ud, Mu'adz bin Jabal, Abu Darda ', Imam Abu Hanifah and Imam Ahmad bin Hanbali. This group has a dalil with the general meaning of Q.S.8: 75 that relatives in general are more important than al muwalah, al muakha 'and al hijrah. Because, these three types of relationships in early Islam were the main cause of inheritance('Ajuz, 1986:222).

Then, they also has a dalil with the narration of Umar bin Khattab, that the Prophet Muhammad said that the brother of the mother is the heir to the person who does not have an heir. Based on this riwayat, Umar bin Khattab ordered Abu Ubaidah to give the inheritance of the person who was killed to the brother of his mother(Washil, 1995:200).

Furthermore, the second group also has a dalil with a riwayatsourced from Nafi 'bin Ibn Hibban. When Thabit bin Dahdahah passed away and did not have heirs of ashabul furudh and ashobah. The problem in his case reached to the Prophet Muhammad, then he gave Tsabit's property to the son of his sister named Lubanah bin Abdu Al Mundzir(Washil, 1995:201).

After describing the two opinions above and their respective dalil, the second opinion is certainly stronger than the first opinion. The dalilused by the first opinion is a very weak, it is mursal hadith. Meanwhile, the second argument using the general meaning of Q.S, 8:75 explains the position of relatives in general, dzawil arham is a part of the relatives. Ibn Katshir explained that this ayat was revealed about al muwala, al muakha and al hijrah as the cause of inheritance. So that getting an inheritance because the reasons for kinship become more important than these three factors(Washil, 1995:201).

Then, in thedalil of the second opinion of the two Sahabat, they have given an example of the practice of giving inheritance to dzawil arham. Namely in the story of Umar bin Khattab who ordered Abu Ubaidah to give 
inheritance to the relatives of dzawil arham when there were no heir groups of ashabul furudh and ashobah. Continuing the practice of Sahabat is certainly more important to do than leaving it('Ajuz, 1986:223).

In maslahah aspect, giving inheritance to dzawil arham will be more important. Because when someone experiences a problem or gets an accident, then, his relatives are the people who care most about him(Nurhaliza, 2018). So that the relationship between relatives, even though dzawil arham will certainly be stronger than that of baitul mal. A person's relationship with baitul mal is a bond of faith only. Meanwhile, someone's relationship with dzawil arham has kinship ties and bonds of faith(Shesa, 2018).

In anotherriwayat, Imam Syafi'i is also argues that dzawil arham has the right more than baitul mal(Qonun, 2010:276). He has this opinion because he saw that the management of the Baitul Mall was not suitable. There is a change in governance compared to the early phase of Islam. So he also agrees that dzawil arham has a right to get an inheritance if it meets the requirements.

Chart. 5

Ulama's Opinion on Inheritance Rights of Dzawil Arham

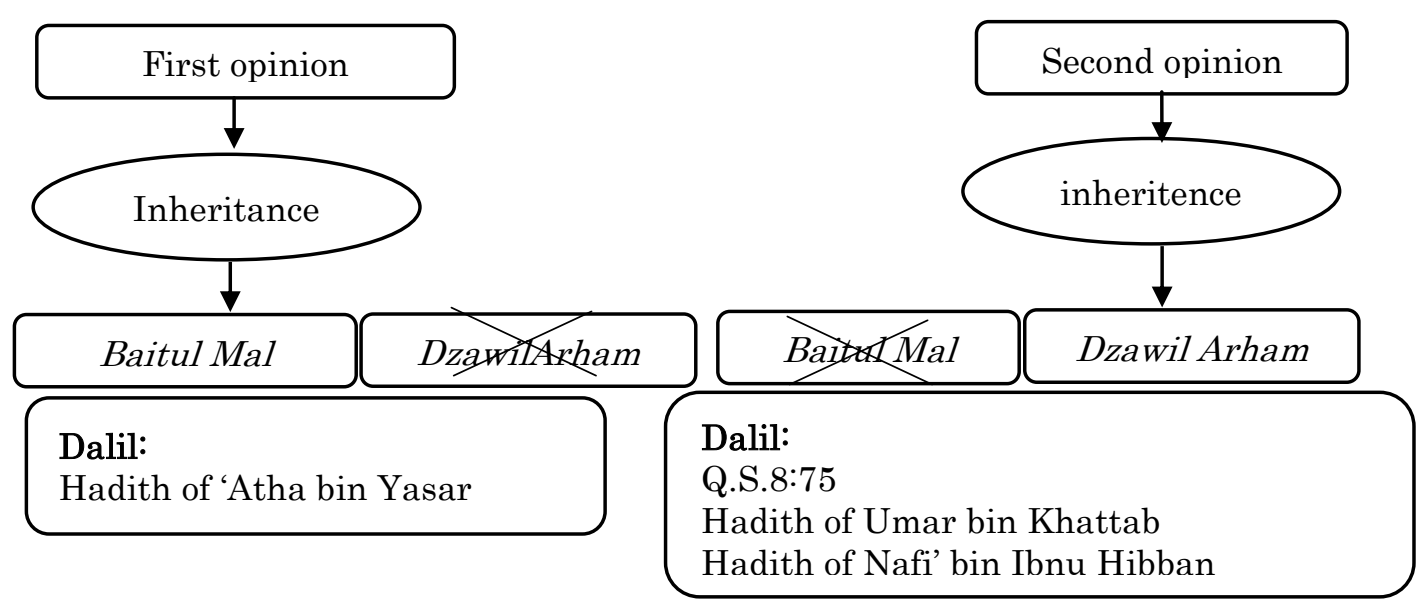

\section{Requirements for the inheritance of Dzawil Arham}

Sahabat and Ulama who allow the dzawil arham to get inheritance provide several conditions. So that dzawil arham can accept it or not depending on the existing conditions. The conditions for the inheritance of dzawil arham are as follows: there is no ashabul furudh inheritance group at all; there is no ashobah inheritance group at all; and there is no ashabu ar-raad (Washil, 1995:202).

Because if there is still a group of heirs of ashabul furudh and ashobah, then their share of the inheritance will be determined first. Meanwhile, ashabu ar-raad, namely the ashabul furudh group that has the right to take the remaining assets after taking their respective heir. They are all ashabul furudh apart from husband, wife, father and grandfather. 
Chart. 6

Requirements for the inheritance of dzawilarham

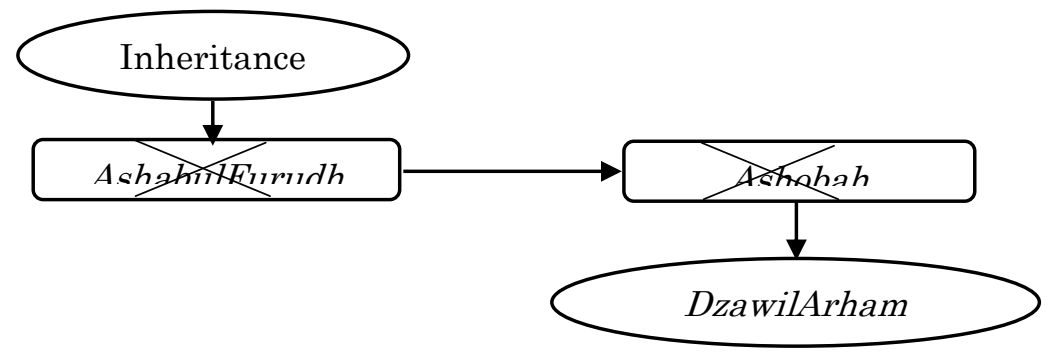

\section{The Concept Of The Inheritance Of Dzawil Arham}

If the heir of dzawil arham is alone, both male and female, then all inheritance is given to him. However, if the number is more than one person or the group is different, then there are three types of ijtihad mazhab ulama in the solution.

\section{Ahlu Al-Rahim}

That is who has opinion that all the positions of dzawil arham are the same. Close and distant relatives, men and women all have the same rights. So that if dzawil arham get inheritance, then the assets are divided based on the number of existing heirs. In this mazhab there is no difference in portion and status, because all members of the heir are the same rights and positions('Ajuz, 1986:223).

\section{Ahlu At-Tanzil}

Namely positioning furu 'inheritance to each ushul. This means that every member of the heirs of the dzawil arham will be considered the heirs of the first line from where they came from. The offspring of the biological daughter will be considered as the biological daughter. The offspring of a granddaughterwill be considered a granddaughter. Therelatives from father's line, and mother's line will be considered as father and mother. The offspring of brother's line will be considered as brothers. Uncle's descendants will be considered uncles. So they were returned to their original relatives('Ajuz, 1986:224).

In this Mazhab, each portion of the dzawil arham is given according to its original quota. If the origin is as ashbul furudh, then the dzawil arham group receives an inheritance in the category of ashabul furudh. However, if the origin is as ashobah, then they accept the category of ashobah('Ajuz, 1986:224).

Then, the process of hijab and mahjub also applies to themazhab atTanzil. The inheritance group that is closer to the deceased can prevent further relatives. So that the process of determining the part of themazhab at-Tanzil is exactly the same as the settlement of inheritance in ashabul furudh and ashobah.

\section{Ahlu Al-Qorobah}

Mazhabof al-Qorobah gives inheritance to the dzawil arham based on the line of kinship. The practice of its implementation is exactly like the legacy of ashobah. So that only one group will get inheritance. Because the closer heir was blocking the far heir. In the practice of ashobah, there cannot 
be two groups of ashobah in one case. The remaining assets that belong to the first group of ashobah cannot be inherited by the sgives inheritance econd group ashobah(Qonun, 2010:283).

In the mazhab of al-Qorobah there are three types of categories in selecting the most entitled heirs. That is the most powerful cause (quwwatu as-sabab), the degree closest to the deceased (qurbu ad-darojah) and the strongest relative to the deceased (quwwatu al-qorobah)(Washil, 1995:204).

If all groups of dzawil arham exist in all kinship lines, bunuwah, ubuwah, ukhuwah, and 'umumah, then the one who gets the inheritance is the strongest because his relative to the deceased is the bunuwah line. However, if the dzawil arham is only on one line, for example on the bunuwah line, then those who gets the inheritance are the descendants of the biological daughter not the descendants of the granddaughter Because the degree of kinship of the biological daughter's offspring is closer to the deceased than the offspring of the female grandchildren. Meanwhile, the selection through quwwatul qorobah takes place on the ukhuwah line and the 'umumah line. Dzawil arham from the descendants of siblings or siblings has the right more than the offspring of stepbrothers or sisters(Qonun, 2010:285-286).

Chart. 7

The concept of the inheritance of dzawilarham

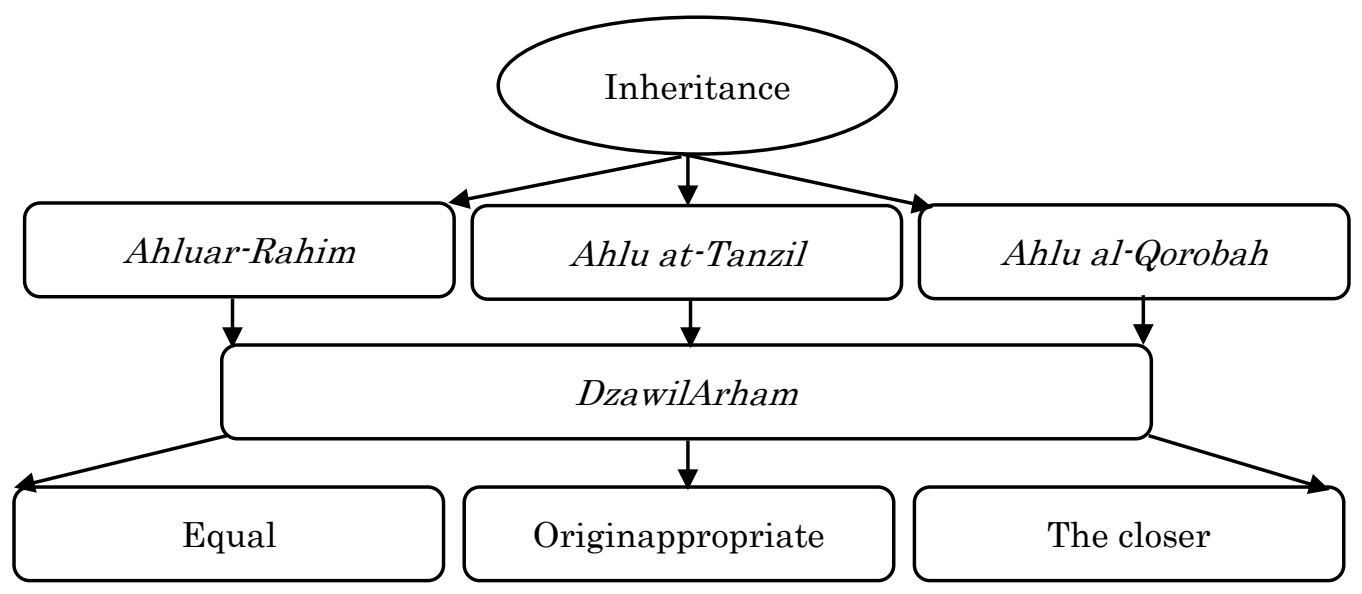

\section{The Counting Method of DzawilArham Inheritance}

First case: A person dies, leaving an heir consisting of sons from biological daughters, mother's siblings, siblings' daughters and biological uncle's daughters.

Chart. 8

\section{Case overview}

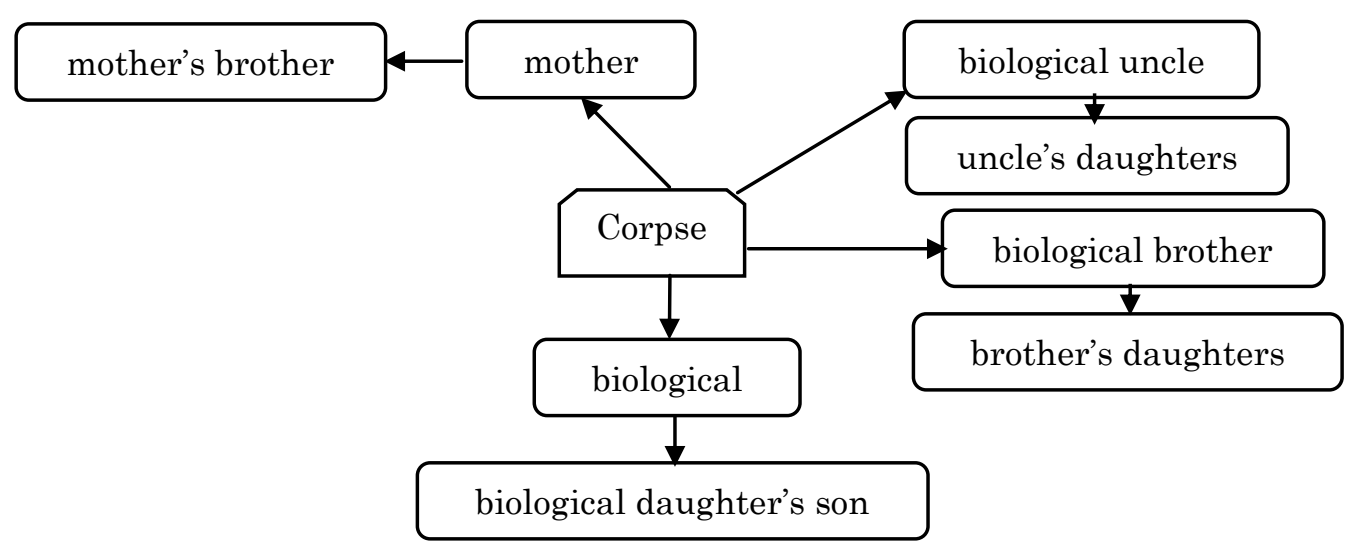


Table. 1

The Settlement Case of the Dzawil Arham Model Ahlu ar-Rahim

\begin{tabular}{|l|c|c|c|}
\hline No. & Heirs & Share & Statement \\
\hline 1. & Biological daughter's son & 1 & $1 / 4 \times$ assest's total \\
\hline 2. & Mother's brother & 1 & $1 / 4 \times$ assest's total \\
\hline 3. & Biological brother daughters & 1 & $1 / 4 \times$ assest's total \\
\hline 4. & Biological uncle's daughters & 1 & $1 / 4 \times$ assest's total \\
\hline
\end{tabular}

Explanation: Assets are divided according to the number of dzawil arham.

They get the same heir without any differences. Each gets 1/4.

Table. 2

The Settlement Case of Dzawil Arham Model Ahlu at-Tanzil

\begin{tabular}{|l|c|c|c|c|}
\hline No. & Heirs & Regarded as & Share & $\begin{array}{c}\text { Origin } \\
\text { Problem(6) }\end{array}$ \\
\hline $\mathbf{1 .}$ & $\begin{array}{c}\text { Biological daughter's } \\
\text { son }\end{array}$ & $\begin{array}{c}\text { biological } \\
\text { daughter }\end{array}$ & $1 / 2$ & $3 / 6$ \\
\hline $\mathbf{2 .}$ & Mother's brother & Mother & $1 / 6$ & $1 / 6$ \\
\hline $\mathbf{3 .}$ & $\begin{array}{c}\text { Biological brother's } \\
\text { daughters }\end{array}$ & $\begin{array}{c}\text { biological } \\
\text { brother }\end{array}$ & AshobahBinnafsi & $2 / 6$ \\
\hline $\mathbf{4 .}$ & $\begin{array}{c}\text { Biological uncle's } \\
\text { daughters }\end{array}$ & $\begin{array}{c}\text { biological } \\
\text { uncle }\end{array}$ & Mahjub(deterred) & - \\
\hline
\end{tabular}

\section{Explanation:}

Stage I, all of the heirs of dzawil arham are entered into the calculation table, the biological daughters's son, the mother's siblings, the daughters of the siblings and the daughters of the biological uncle.

Stage II, all of the heirs of dzawil arham are returned to their origin positions. Biological daughters's son are considered as the biological daughters, mother's siblings are considered as the mothers, siblings 'daughters are considered as biological siblings and biological uncles' daughters are considered as biological uncles.

Stage III, the share of each heir is determined in accordance with the portion of origin. So, the biological daughter's son get $1 / 2$, the mother's siblings get $1 / 6$, the siblings 'daughters as ashobah binnafsi and the biological uncle's daughters do not get any part because they are blocked by the siblings' daughters.

Stage IV, look for the Smallest Federation Multiples between the maqom (denominator) of the son's biological daughter (2) and the mother's brother (6), namely number 6.Thus, the son of the biological daughter gets $3 / 6$, the mother's brother gets 1/6 the daughter of a sibling as ashobah binnafsi gets $2 / 6$ and her uncle's daughter does not get a share because of his mahjub. 
Table. 3

The Settlement Case ofDzawil Arham Model Ahlu al-Qorobah

\begin{tabular}{|l|c|c|c|}
\hline No. & Heirs & Share & Statement \\
\hline 1. & Biological daughter's son & Getting asset & All of assets \\
\hline 2. & Mother's brother & Mahjub(deterred) & - \\
\hline 3. & $\begin{array}{c}\text { Biological brother's } \\
\text { daughters }\end{array}$ & Mahjub(deterred) & - \\
\hline 4. & $\begin{array}{c}\text { Biological uncle's } \\
\text { daughters }\end{array}$ & Mahjub(deterred) & - \\
\hline
\end{tabular}

Explanation: Only one person get inheritance, namely sons and daughters. While others are blocked, because the bunuwah line relatives are stronger than the other relatives. So all property is given to the sons and daughters of the biological.

Second Case: A person dies, leaving an heir consisting of the granddaughter of the biological daughter and the great-granddaughter of the biological granddaughter.

Chart. 9

Case overview

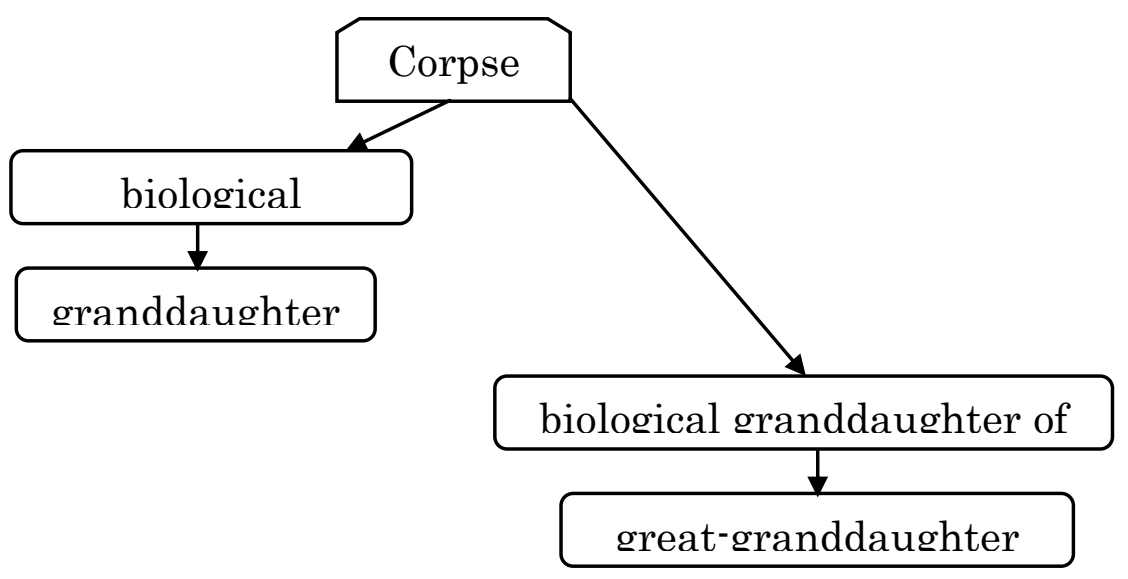

Table. 4

The Settlement Case of Dzawil Arham Model Ahlu ar-Rahim

\begin{tabular}{|l|c|c|c|}
\hline No. & Heirs & Share & Statement \\
\hline 1. & Granddaughter of biological daughter & 1 & $1 / 2 \times$ total assets \\
\hline 2. & Great grandson of biological daughter & 1 & $1 / 2 \times$ total assets \\
\hline
\end{tabular}

Explanation: Assets are divided according to the number of dzawil arham.

They get the same share without any differences. Each got 1/2. 
Table. 5

The Settlement Case of Dzawil Arham Model Ahlu at-Tanzil

\begin{tabular}{|l|c|c|c|c|}
\hline No. & Heir & Regarded as & Share & $\begin{array}{c}\text { Origin } \\
\text { problem } \\
\mathbf{4}\end{array}$ \\
\hline 1. & $\begin{array}{c}\text { Granddaughter of } \\
\text { biological daughter }\end{array}$ & $\begin{array}{c}\text { biological } \\
\text { daughter }\end{array}$ & $1 / 2$ & $3 / 4$ \\
\hline $\mathbf{2 .}$ & $\begin{array}{c}\text { Great Grandson of } \\
\text { biological daughter }\end{array}$ & $\begin{array}{c}\text { granddaughter } \\
\text { of biological } \\
\text { daughter }\end{array}$ & $1 / 6$ & $1 / 4$ \\
\hline
\end{tabular}

\section{Explanation:}

Stage I, all of heirs of dzawil arham are entered into the calculation table, namely the granddaughter of the biological daughter and the great-grandson of the biological granddaughter.

Stage II, all of the heirs of dzawil arham are returned to their origin positions. The granddaughter of a biological daughter is considered a biological daughter and the grandchild of a biological granddaughter is considered a biological granddaughter.

Stage III, the share of each heir is determined in accordance with the portion of origin. So, the granddaughter of the biological daughter gets $1 / 2$ and the grandson of the biological granddaughter gets $1 / 6$.

Stage IV, First, look for the Smallest Federation Multiples between maqom (denominator) part of the granddaughter of the biological daughter (2) and the great-grandson of the biological granddaughter (6), namely number 6.Thus, the granddaughter of the biological daughter gets $3 / 6$ and the grandson of the biological granddaughter gets $1 / 6$. Since there are still some leftovers, this case is a category of Raad problem. Second, their combined shares are used as the origin of the problem, which is number 4 . So that each gets $3 / 4$ and $1 / 4$ (fardhon and roddan).

Table. 6

The Settlement Case of Dzawil Arham Model Ahlu al-Qorobah

\begin{tabular}{|l|c|c|c|}
\hline No. & Heir & Share & Statement \\
\hline 1. & $\begin{array}{c}\text { Granddaughter of biological } \\
\text { daughter }\end{array}$ & Getting heir & All assets \\
\hline 2. & $\begin{array}{c}\text { Great grandson of biological } \\
\text { daughter }\end{array}$ & Mahjub(deterred) & - \\
\hline
\end{tabular}

Explanation: Only one person get inheritance, namely the granddaughter of the biological daughter. While great-grandchildren are hindered, because the relatives of the grandchildren are closer to the deceased than the relatives of the great-grandchildren. So all property is given to the granddaughter of the biological daughter.

Third Case: A person dies, leaving an heir consisting of the daughter of a biological sister, the daughter of a step sister of father and the daughter of step sister of mother. 
Chart. 10

Case overview

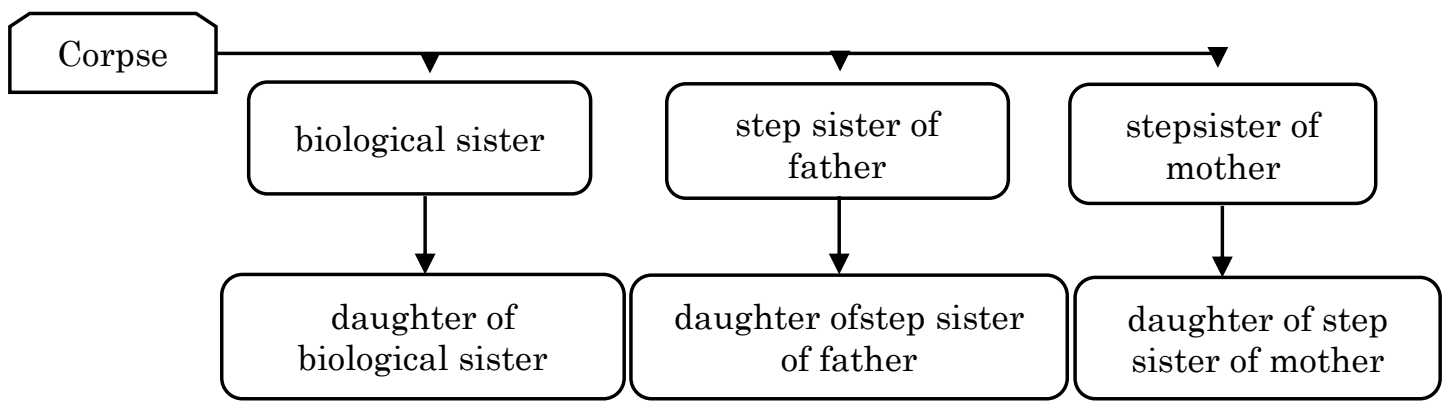

Table. 7

The Settlement Case of Dzawil Arham Model Ahlu ar-Rahim

\begin{tabular}{|l|c|c|c|}
\hline No. & Heir & Share & Statement \\
\hline 1. & Biological sister's daughter & 1 & $1 / 3 \times$ total assets \\
\hline 2. & Daughter of step sister of father & 1 & $1 / 3 \times$ total assets \\
\hline 3. & Daughter of step sister of mother & 1 & $1 / 3 \times$ total assets \\
\hline
\end{tabular}

Explanation: Assets are divided according to the number of dzawil arham. They get the same share without any differences. Each of them gets 1/3.

Table. 8

The SettlementCase of Dzawil Arham Model Ahlu at-Tanzil

\begin{tabular}{|l|l|l|c|c|}
\hline No. & \multicolumn{1}{|c|}{ Heirs } & \multicolumn{1}{|c|}{ Regarded as } & Share & $\begin{array}{c}\text { Origin } \\
\text { problem (5) }\end{array}$ \\
\hline 1. & Biological sister's daughter & Biological sister & $1 / 2$ & $3 / 5$ \\
\hline 2. & $\begin{array}{l}\text { Daughter of step sister of } \\
\text { father }\end{array}$ & Step sister of father & $1 / 6$ & $1 / 5$ \\
\hline 3. & $\begin{array}{l}\text { Daughter of step sister of } \\
\text { mother }\end{array}$ & Step sister of mother & $1 / 6$ & $1 / 5$ \\
\hline
\end{tabular}

\section{Explanation:}

Stage I, all heirs of the dzawil arham are entered into the calculation table, namely the daughter of the biological sister, daughter of step sister of fatherand the daughter of step sister of mother

Stage II, all the heirs of dzawil arham are returned to their origin positions. The daughter of a biological sister is considered as biological sister, Daughter of step sister of father is considered as step sister of father and Daughter of step sister of motheris considered as step sister of a mother.

Stage III, the share of each heir is determined in accordance with the portion of origin. So, the biological sister's daughter gets $1 / 2$, the daughter of step sister of father gets $1 / 6$ and the step sister's daughter of mother gets 1/6.

Stage IV, First, look for the Smallest Federation Multiples between maqom (denominator) part of the biological sister's daughter (2), the daughter of the step-sister of father (6) and the daughter of the step-sister of mother (6), which is the number 6 . Therefore, the daughter of the biological sister gets $3 /$ 6 , step sister's daughter of father gets $1 / 6$ and step sister's daughter of mother gets $1 / 6$. Since there are still some leftovers, this case is a category of Raad problem. Second, the combined shares of the three of them are used as the 
origin of the problem, namely number 5 . So that each gets $3 / 5,1 / 5$ and $1 / 5$ (fardhon and roddan).

Table. 9

The Settlement Case of Dzawil Arham Model Ahlu al-Qorobah

\begin{tabular}{|l|c|c|c|}
\hline No. & Heirs & Share & Statement \\
\hline 1. & Biological sister's daughter & Getting heir & All assets \\
\hline 2. & Daughter of step sister of father & Mahjub(deterred) & - \\
\hline 3. & Daughter of step sister of mother & Mahjub(deterred) & - \\
\hline
\end{tabular}

Explanation: Only one person get inheritance, namely the biological sister's daughter. Meanwhile, the daughter of a step sister of father and the daughter of a step sister of mother did not get a share, because the relatives of the sister's daughter were stronger towards the deceased. Because the line of relatives is from the father's and the mother's line, while the step line from father is only from father's line and step line from mother is only from mother's line. So all the assets were given to the biological sister's daughter.

\section{Conclusion}

As a conclusion in this study, that the heirs of dzawil arham have kinship to the deceased bilaterally, namely through the male line and the female line. But in general, the dzawil arham kinship is mostly through the female line. Their inheritance status is categorized as the third group of inheritors. Dzawil arham get inheritance if there are no heirs from the ashabul furudh and ashobah groups.

Dzawil arham has inheritance rights according to the majority of sahabah and mazhab of the Ulama of fiqh. The settlement of the dzawil arham case has three characteristics, the ahlu ar-rahim mazhab, the ahlu attanzil mazhab and the ahlu al-qorobah mazhab. In the process of determining and counting the parts of dzawil arham, ahlu ar-rahim equalizes and shares all of the dzawil arham without any difference, ahlu at-tanzil returns the dzawil arham to the origin of its relative to the deceased, so that their portion corresponds to their respective origins. While ahlu al-qorobah completes the heir count of dzawil arham with the ashobah model. That is, inheritance is for one person or group only, because close dzawil arham hinders distant relatives. 


\section{References}

'Ajuz, A. M. Al. (1986). Al Mirats Al 'Adil fi Al Islam baina Al Mawarits Al Qadimah wa Al Haditsah. Muassasah Al Ma'arif.

Achmad Beadie Busyroel Basyar. (2020). Perlindungan Nasab Dalam Teori Maqashid Syariah. Maqashid, 3(1), 1-16. https://doi.org/10.35897/maqashid.v3i1.286

Amri, M. S., \& Tulab, T. (2018). Tauhid: Prinsip Keluarga Dalam Islam (Problem Keluarga Di Barat). In Ulul Albab: Jurnal Studi dan Penelitian Hukum Islam (Vol. 1, Issue 2). https://doi.org/10.30659/jua.v1i2.2444

Ar-Rozi, S. I. M. ibn A. B. ibn A. Q. (2003). Mukhtarus Shohhah. Dar El Hadith.

Aziz, F. bin A. (2006). Risalatani fi Ilmi Al-Faraidh. Daar Kunuz.

Darussalam, A. (2017). Pernikahan Endogami Perspektif Islam dan Sains. Tahdis: Jurnal Kajian Ilmu, g(1), 1-20. http://journal.uinalauddin.ac.id/index.php/tahdis/article/download/3997/3695

Fitriyati, Y., \& Zuhdi, M. (2020). Rights and Obligations of the Guardians To the Inheritance of Mental Disabled Children. Nurani: Jurnal Kajian Syariah Dan Masyarakat, 20(2), 179-186. https://doi.org/10.19109/nurani.v20i2.6635

Hadi, A. C. (2016). Sistem Kewarisan Islam Dan Pemerataan Distribusi Kekayaan. Kordinat: Jurnal Komunikasi Antar Perguruan Tinggi Agama Islam, 15(2), 295-312. https://doi.org/10.15408/kordinat.v15i2.6335

Haryanto, J. T. (2015). RELASI AGAMA DAN BUDAYA DALAM HUBUNGAN INTERN UMAT ISLAM The Relationship between Religion and Cultures among Muslims. Jurnal SMaRT, 1(1), 41-54.

Hasibuan, N. K. (2020). IMPLEMENTASI HUKUM WARIS PADA MASYARAKAT ADAT MANDAILING PERANTAUAN (STUDI PADA PARDOMUAN MUSLIM SUMATERA UTARA KOTA PALANGKA RAYA). TAHKIM, Jurnal Peradaban Dan Hukum Islam, 3(2), 115-130.

Indonesia, K. A. R. (2014). Al- Qur'ân al- Karîm dan Terjemahannya. Halim.

Katsir, A. F. I. bin U. I. (1999). Tafsir Al qur'an Al 'Adzhim (II). Daar Thoibah.

Khalifah, M. T. A. A. 'Ala. (2005). Ahkam Al Mawarits Dirasah Tathbiqiyah. Dar Al Salam.

Kiswanto, F. (2019). KEDUDUKAN HUKUM ANAK LAKI-LAKI DAN PEREMPUAN TERHADAP PEWARISAN DALAM PERKAWINAN BATAK - MINANGKABAU DI KEL. TEGAL SARI III, KEC. MEDAN AREA, KOTA MEDAN. Universitas Sumatera Utara.

Manangin, M. S. A., Nurmala, L. D., \& Martam, N. K. (2020). Pengalihan Atas Harta Warisan Di Indonesia. DiH: Jurnal Ilmu Hukum, 16(2), 177189. https://doi.org/10.30996/dih.v16i2.3345

Nurhaliza, M. (2018). Tanggung Jawab Terhadap Kerabat dalam Al-qur'an. Universitas Islam Negeri Ar-Raniry.

Qonun, L. Q. A. F. F. S. wal. (2010). Fiqh Al Mawarits. Universitas Al Azhar.

Qurtubi, A. A. M. bin A. A. A. Al. (n.d.). Jami' Li Ahkamil Qur'an (V). Daar Alam Al Kutub.

Ritonga, R. (2020). Sistem Kewarisan Adat Masyarakat Muslim Suku Tengger Perspektif Hukum Islam. El Ahli: Jurnal Hukum Keluarga Islam, 1(1), 1-19. 
Ritonga, R. (2021a). Ta'yin; Penentuan Bagian Ahli Waris Sebelum Pembagian Warisan. Al-Syakhshiyyah, 3(1), 29-47. https://doi.org/10.35673/as-hki.v3i1.1348

Ritonga, R. (2021b). The Firts Class Of Women Heir Member In The Observation Of Surah An-Nisa Ayat 11, 12 , DAN 176. Al-' A Dalah: Jurnal Syariah Dan Hukum Islam, 6(1), 1-17. https://doi.org/10.31538/adlh.v6i1.1362

Saadat, S. (2009). Human embryology and the holy quran: an overview. International Journal of Health Sciences, 3(1), 103-109. http://www.ncbi.nlm.nih.gov/pubmed/21475518\%0Ahttp://www.pubmedc entral.nih.gov/articlerender.fcgi?artid=PMC3068791

Shesa, L. (2018). Keterjaminan Kedudukan Dzaul Arham Dalam Kewarisan Islam Melalui Wasiat Wajibah. Al-Istinbath : Jurnal Hukum Islam, 3(2), 146-166. https://doi.org/10.29240/jhi.v3i2.615

Sitti Suryani, N. H. dan S. A. (2018). HAK KEWARISAN ZAWIL ARHAM (PERSPEKTIF MAZHAB HANAFIYAH DAN SYAFI'IYAH). Jurnal Ilmu Syariah, Perundang-Undangan Dan Ekonomi Syariah, Juli-Desember, 146-155.

Taqiyuddin, H. (2020). Hukum Waris Islam Sebagai Instrumen Kepemilikan Harta. Asy-Syari'ah, 22(1), 1-20. https://doi.org/10.15575/as.v22i1.7603

Wahyuni, A. (2018). Sistem Waris Dalam Perspektif Islam dan Peraturan Perundang-undangan Di Indonesia. SALAM: Jurnal Sosial Dan Budaya Syar-I, 5(2), 147-160. https://doi.org/10.15408/sjsbs.v5i2.9412

Washil, N. F. M. (1995). Fiqhu Al Mawarits wa Al Wasiyah. Dar Al Salam. 